\title{
LEASES AND THE RULE AGAINST PERPETUITIES
}

\author{
EDWIN H. ABBOT, JUNIOR \\ of the Boston Bar \\ $\mathbf{I}$ \\ INTRODUCTION
}

The purpose of this article is to consider the application of the rule against perpetuities to leases. A leasehold estate has certain peculiarities which distinguish it, as a practical matter, from other estates in land. At common law it required no livery of seisin, and so could be created to begin in futuro. Although it is not an estate of freehold the duration of the estate may be practically unlimited-it may be for 999 years or even in perpetuity. The reversion after an estate for years is necessarily vested, no matter how long the term of the lease may be, yet the leasehold estate is generally terminable at an earlier time upon numerous conditions subsequent, defined in the lease. In other words the leasehold estate determines without condition by the effluxion of the term defined in the lease but such termination may be hastened by the happening of one or more conditions. The application of the rule against perpetuities to such an estate presents special problems. The purpose of this article is to consider the application of the rule to the creation, termination and renewal of leases; and also its effect upon options inserted in leases.

\section{II}

\section{CREATION}

A leasehold estate may be created to begin in futuro, since livery of seisin was not at common law required for its creation. Unless limited by the rule a contingent lease might be granted to begin a thousand years hence. But the creation of a contingent estate for years to begin a thousand years hence is for practical reasons just as objectionable as the limitation of a contingent fee to begin at such a remote period by means of springing or shifting uses, or by the device of an executory devise. It is not surprising therefore that the rule against perpetuities has been held to apply to the original creation of contingent estates for years, and to prohibit their creation at a period too remote. ${ }^{1}$

${ }^{1}$ Hope v. Gloucester (1855) 7 DeG. M. \& G. 647; Redington v. Browne (1893) I. R. 32 Ir. 347 ; Johnson v. Preston (I907) 226 Ill. 447. 
In Hope v. Gloucester, ${ }^{2}$ certain lands were conveyed by C. in 1529 by deed to the Corporation of Gloucester, the rents to be applied to a charity, and the city covenanting that it would from time to time, when and as a certain farm should become vacant; grant a lease thereof for $3^{I}$ years at a certain rent to such one of the heirs of the body of $B$. as should then request such lease. This covenant the city observed for over 300 years, and until the expiration of a lease granted in 18 I5. At the expiration of that lease a person within the description of the indenture demanded a lease which was refused, whereupon he brought this bill for specific performance which was resisted upon the ground that the covenant was unenforceable specifically under the rule against perpetuities. This defense was sustained, the court deciding that a perpetual covenant to grant successive terms of 3 I years to such one of the heirs of the body of B. as should first apply therefor violated the rule and was unenforceable specifically.

A similar result was reached in Attorney Gen. v. Greenhill, ${ }^{3}$ in which it was held that a gift of lands to a charity with a perpetual direction to lease to kindred of the grantor was good so far as the gift was concerned, but that the direction with respect to leasing was void as a perpetuity.

So also in Redington $v$. Brozeme 4 a lease for three lives or 99 years, whichever should be longest, was granted on May I, 1798. In I8I4 while this term was still existent the reversioner covenanted that at the expiration of the prior lease he would grant a further lease for three unspecified lives. This was a bill in equity to enforce that covenant, to which the rule against perpetuities was urged as a defense. The court intimated that a present grant of an estate for years to take effect at the expiration of a present term for 99 years would not, if in all respects vested, violate the rule, but held that the estate created by the present covenant was not of that character since the nomination of the lives and so the period of the estate might not be determined until a period too remote.

In Johnson v. Preston ${ }^{5}$ a will devised certain real estate in trust to hold for the term of 25 years "from and after the probate of this will."

It was held that this devise was void under the rule since the will might not be probated within 2I years of the testator's death and so the event on which the estate was to begin might not happen within that time.

It may, however, be observed that in all these cases some essential element of the estate for years would not necessarily be determined within the period of the rule. In Hope v. Gloucester the lessee might

${ }^{2} 7$ DeG. M. \& G. 647 .

(1863) 33 Beav. 193, 9 Jur. N. S. I307.

' L. R. 32 Ir. 347.

¿226 I11. 447. 
and indeed could not be so determined; in Redington $v$. Browne the lives by which the term was to be measured, and so the term itself, remained uncertain; in Johnson v. Preston the starting point of the term might not be ascertained within the required period. In all these cases, therefore, the leasehold remained contingent and so within the strict letter of the rule.

A more difficult case is that in which a definite term for years is granted to a definite person to begin without any contingency at a period beyond the ordinary limits of the rule-for example, a term for 50 years to $A$. to begin 50 years hence. Here the term and the lessee are ascertained exactly and without contingency, although the term is not to take effect for 50 years from date. On this point the wriţer has found no direct authority. It may be urged that $\mathrm{A}$. has in prcesenti not a strictly vested estate but a mere interesse termini, and therefore does not strictly satisfy the rule. But this argument is at best a technical one. The situation may be met and overcome if the owner of the property convey to a straw man who immediately reconveys to the grantor for 50 years, remainder to A. for 50 years, remainder in fee to the grantor. Here all the estates are vested and so not obnoxious to the rule. If this be so it is difficult to see why the term to A. may not be directly created without the intervention of the straw man. For practical purposes A.'s term is vested in either case. The only effect of invoking the rule is to prohibit the direct creation of a term to take effect without contingency 50 years herice, although the result may be attained by utilizing a straw man and a somewhat more elaborate procedure.

A slightly different case tends to sustain this view. Suppose a lease for 99 years has been granted to A. and that thereafter the reversioner grants another lease to $B$. to take effect at the expiration of the 99 year lease. According to an intimation in Redington v. Browne, supra, this would be good. Indeed the argument to support this view seems unassailable. The reversion after the 99 year term is vested and so not obnoxious to the rule. The reversioner might therefore convey the fee, subject to the lease, to $B$. If so he may clearly carve out any lesser vested estate-as an estate for years or for life or in tail-to take effect at the expiration of the 99 year lease. The situation is in no way different from that which would have existed had the original lessor leased to A. for 99 years, with remainder for 50 years or for life or in tail to B. Plainly if such vested estates, limited to take effect at the expiration of the 99 year lease, might have been originally created, they may subsequently be created by the reversioner by a separate instrument. Nor does this conclusion conflict in any way

-Gray, Perpetuities (3d ed. I915) s. 71; Hall, Landlord \& Ten. 16. See Barwick's Case (1597) 5 Co. 93 b, 94 b; Weld v. Traip (1859, Mass.) I4 Gray, 330. 
with the actual decision in Redington $v$. Brozene. ${ }^{7}$ In that case the extent of the additional term was not to be determined until a period too remote, so that there could be no vesting of the estate within the period of the rule.

III

\section{TERMINATION}

Although a lease may be given for an unlimited term or even in perpetuity, ${ }^{8}$ the reversion is clearly not obnoxious to the rule, ${ }^{8}$ since it is a vested interest. Indeed the reversion is never out of the lessor. Thus in Sioux City, etc. Co. v. Trust Co. ${ }^{10}$ the Sioux City Co. made a lease of its property for roo years to another company, and subsequently mortgaged its reversion and rights under the lease to secure an issue of bonds. On foreclosure it was urged that both lease and mortgage violated the rule. It was held that since the reversion after the roo year lease was vested it was not within the rule. So also in Redington v. Brozene $e^{11}$ it was intimated, though not actually decided, that the reversioner after a 99 year lease had a vested interest out of which he could grant a further vested term for years. Indeed the large number of cases ${ }^{13}$ which sustain covenants for renewal inserted in leases for terms of more than 2I years necessarily involve a recognition that the lessor still possesses a vested interest out of which the renewal term may be carved. In a word there seems no escape from the conclusion that the reversion after a lease, no matter how long the lease may be, is a vested interest not obnoxious to the rule.

Curiously enough this point was overlooked in Hanley v. Kansas \& $T$. Coal Co. ${ }^{14}$ which on this point is not to be supported. In that case W. devised lands to $C$. in fee in trust for Mariah Woolage and her descendants for 200 years, the remainder in fee to vest at the expiration of that time in the county in which the lands should then be situated. The trustee declined the trust. The plaintiffs (descendants of Mariah Woolage, who had died intestate) filed their bill alleging that defendant had wrongfully seized the lands and praying that title

\footnotetext{
${ }^{7}$ L. R. 32 Ir. 347.

'Atkinson v. Orr (1889) 83 Ga. 34; Cook v. Bisbee (1836, Mass.) 18 Pick. 527; Delhi School Dist. v. Everett (1883) 52 Mich. 314; Folts v. Huntley (183I) 7 Wend. 2ro; Lewis v. Effinger (1858) $30 \mathrm{~Pa}$. St. 28I.

'Sioux City Co. v. Trust Co. (1897, C. C. A. 8 C.) 82 Fed. 124; Redington v. Browne, L. R. 32 Ir. 347 ; Gray, Perpetuities, ss. 209, 210.

${ }^{10}$ See supra, note 9.

"See supra, note 9 .

${ }^{12}$ Gray, Perpetuities, ss. 209, 210; Sioux City Co. v. Trust Co. (1897, C. C. A. 8 C.) 82 Fed. I24; Redington v. Browme, L. R. 32 Ir. 347.

${ }^{13}$ See post, sec. IV.

14 (Igor, C. C. W. D. Ark.) rio Fed. 62.
} 
be quieted in them. The defendant demurred. The court held that the gift of the remainder in fee to the county was a contingent gift which was void under the rule; that the equitable if not the legal fee was in the plaintiffs; but that a bill to quiet title could not be maintained by persons out of possession. This case seems right in holding the gift over to the county contingent and void, since the county entitled to take would not be ascertained for 200 years; it seems wrong, however, in holding that the fee was in the plaintiffs, since if the gift to the county be held void, there was a reversion in fee in the heirs of the devisor, and as this reversion vested at the devisor's death it would not be obnoxious to the rule. This phase of the case seems to have been overlooked by the court.

Yet the status of the reversion or vested remainder after a lease for a term of more than 2I years is somewhat peculiar. It.must come in by effluxion of time and without contingency at the expiration of the term. On the other hand most leases contain covenants in the nature of conditions to be performed by the lessee-such as to pay rent, to pay taxes, to repair, not to assign or underlet, etc. If the covenant be violated and so the condition be broken, the reversioner or remainderman as the case may be may enter and terminate the lease, thus accelerating the reversion or remainder. While the vesting of the reversion or remainder is not dependent upon any condition, the lessee's estate is subject to conditions subsequent which may terminate it prematurely and bring in the remainder or reversion. Thus where the lease is for a period greater than 2I years the lessee's estate is subject to conditions subsequent which as to that estate might conceivably be deemed too remote, while the lessor's estate, which may be accelerated by the happening of those conditions, is still vested whether they happen or not.

It might be urged that the validity of such conditions should be determined with reference to their effect upon the lessee's estate. If so they would on principle be held bad if inserted in any lease for a term of more than 2I years. But this contention has never been raised or decided in any case known to the writer. Moreover, that contention seems contrary both to common sense and to justice. So long as the law permits the creation of terms for more than 2I years, there seems to be no reason to prohibit making such leases subject to conditions subsequent which may lawfully be attached to terms of less length. It would certainly be astonishing if a court should decide that a lessee for 20 years could be evicted for nonpayment of rent, but that this could not be done if the lease were for 22 years. Payment of rent is usually of the very essence of the transaction. The rule is essentially a rule of public policy. It can scarcely be that in such a case any public policy requires protection of the defaulting tenant at the expense of his landlord. If it were necessary, the rule cessante ratione, cessit ipsa lex might well be applied. 
It is not, however, necessary to go so far as this. Viewed from the standpoint of the lessor's estate, the condition is in no way obnoxious to the rule, since that estate is vested. The happening of the condition does not vest the landlord's estate; it merely accelerates his taking possession by right of an estate which is vested whether the condition has happened or not. Moreover the landlord's right of entry may be sustained in this country by the mass of authorities which have upheld rights of entry for condition broken contained in conveyances in fee, ${ }^{15}$ although without consideration of the rule. For all these reasons it would seem that the contention cannot be sustained that a right of entry reserved in a lease for more than $2 \mathrm{I}$ years is bad.

\section{IV}

\section{RENEWAL}

It is of course clear that the fact that a lease for more than $2 I$ years may, by agreement of the parties then interested, be extended or renewed at a remote period, does not affect the present validity of the lease. ${ }^{16}$ Suppose, however, that a lease for over $2 \mathrm{I}$ years contains a covenant for renewal at the option of the lessee. Or suppose such a lease contains a covenant for a perpetual series of such renewals. It has been argued that such a covenant is incident to a present vested interest in the lessee, may be regarded as a part thereof and so, if sustained, furnishes no exception to the rule. But this argument is difficult to support. The question whether the option to renew will ever ripen into a further term depends on the will of the lessee. Until the option is exercised the additional term cannot be said to vest in any strict sense. If therefore the option may be exercised, and the actual vesting of the additional term may take place at a period beyond the limits of the rule, there seems no escape from the conclusion that such option if sustained does form an exception to the rule.

There seems to be no question, however, that such an option is good. It has been consistently sustained for over 200 years in England. ${ }^{17}$

\footnotetext{
${ }^{25}$ Gray, Perpetuities, ss. 305-3II, where the cases are collected.

${ }^{10}$ Gray, Perpetuities, s. 230 et seq.

${ }^{17}$ Bridges v. Hitchcock (1715, H. L.) 5 Bro. P. C. 6; Ross v. Worsop (I740, H. L.) I Bro. P. C. 28I; Furnival v. Crew (1744) 3 Atk. 83, aff'd. H. L.; Atkinson v. Pillsworth (I787, Ir.) I Ridg. App. 449; Palmer v. Hamilton (I793, Ir.) 2 Ridg. App. 535; Rawstorne v. Bentley (1793, Ch.) 4 Bro. Ch. 415; Taylor v. Stibbert (1794) 2 Ves. Jr. 437; London v. Mitford (1807) I4 Ves. Jr. 4r, semble; Brown v. Tighe (I834) 2 Cl. \& F. 396, semble; Dockrill v. Dolan (184r) 3 Ir. Eq. 552; Sheppard v. Doolan (1842) 3 Dr. \& War. I; Copper Mining Co. v. Beach (I823) I3 Beav. 478; Hodges v. Blagrave (I853) I8 Beav. 404; Hare v. Burges (1857) 4 Kay \& J. 45; Pollock v. Booth (I875) Ir. R. 9 Eq. 229; aff'd. ibid. 607; Nicholson v. Smith (I882) 22 Ch. D. 640.
} 
The great weight of authority in this country is to the same effect. ${ }^{18}$ The single case which the writer has found contra ${ }^{10}$ rests on statute. Moreover such a covenant is enforceable in equity, ${ }^{20}$ and runs with the land. ${ }^{21}$

It is true that in most of the English cases cited there is no discussion of the rule. In Bridges $v$. Hitchcock, ${ }^{22}$ which was a bill in equity by the assignee of the lessee specifically to enforce the covenant to renew against the lessor, it was objected that the covenant tended to a perpetuity, but the objection was overruled and the covenant was specifically enforced. In the other cases the point seems not to have been considered. It is, however, conceded that either as an exception to the rule or in spite of it such covenants are valid in England.23 Moreover several of the American cases do expressly consider the validity of such covenants under the rule and uphold them none the less. ${ }^{24}$ But whether the rule be actually discussed or not, the mere weight of decision seems sufficient to establish the result. ${ }^{25}$

This apparent exception to the rule may well be justified on grounds of common sense. There seems to be no legal objection to a long lease with a right in the lessee to terminate it at his election either at the expiration of fixed periods or at any other time. Such termination merely brings in the reversion or the vested remainder of the person who holds the next estate. Furthermore as the termination is entirely in the hands of the lessee, it would seem unobjectionable in any case. It is true that here the lessee has an estate which is unquestionably vested, and so not obnoxious to the rule, whereas in the case of the option to renew he has merely a contingent right to extend his present vested interest. From the point of view of strict legal reasoning this is perhaps a real distinction. But for practical purposes it is of little worth. In either case the continuance of the lessee's estate depends

${ }^{18}$ Banks v. Haskie (I876) 45 Md. 207; Boyle v. Peabody H. Co. (I877) 46 Md. 623 ; Blackmore v. Boardman (1859) 28 Mo. 420 ; Diffenderfer v. Board (1894) 120 Mo. 447; Drake v. Board (I907) 208 Mo. 540; Robinson v. Beard (1893) 140 N. Y. I07; Gomez v. Gomez (I895) I47 N. Y. I95; Hoff v. Royal M. F. Co. (Ig07) Ir7 App. Div. 884; aff'd. I89 N. Y. 555; Thaw v. Gaffney (I9I4, W. Va.) 75 W. Va. 229, 83 S. E. 983.

${ }^{10}$ Morrison v. Rossignol (1855) $5 \mathrm{Ca} .64$.

${ }^{20}$ See cases cited in notes 18 and I9, supra.

${ }^{21}$ Blackmore v. Boardman (I859) 28 Mo. 420 ; Furnival v. Crew (1744) 3 Atk. 83; Taylor v. Stibbert (I794) 2 Ves. Jr. 437; Dockrill v. Dolan (I84I) 3 Ir. Eq. 552. And see cases cited in notes 18 and 19, many of which were between assignees.

2 (I745, H. L.) 5 Bro. P. C. 6.

${ }^{23}$ See London \& S. W. Ry. v. Gomm (I882) 20 Ch. D. 562, 579; Woodall $v$. Clifton [1905] 2 Ch. 257.

24 Banks v. Haskie (1876) 45 Md. 207; Blackmore v. Boardman (1889) 28 Mo. 420; Thaw v. Gafney (1914, W. Va.) 83 S. E. 983.

${ }^{25}$ See Gray, Perpetuities, ss. 305-3II concerning the similar situation in American courts as to the validity of a right of entry in a conveyance in fee. 
on the lessee. Strict application of the letter of the rule would sustain one method of reaching the given result while disapproving of the other. It would mean merely a change in the form or the lease so as to permit the lessee to end a long term instead of to extend a short one. The rule is essentially a practical rule grounded on public policy. If the result may be reached without violating either the letter of the rule or the public policy on which it rests, an apparent exception which permits the result to be attained in a way which at most violates only the letter of the rule may well be sustained:

$\mathrm{V}$

OPTIONS TO PURCHASE THE FEE INSERTED IN LEASES

Suppose that in a lease for more than 2I years the lessor covenants that the lessee at his option may purchase the fee at any time during the term. Is this option valid? The cases generally agree that if an option in gross to purchase back the fee, exercisable beyond the period of the rule, be inserted in a conveyance in fee, such option will not be specifically enforced in equity, since specific enforcement would in effect create a contingent estate which would violate the rule. ${ }^{26}$ If therefore the letter of the rule is to be blindly applied, a similar covenant contained in a lease cannot be sustained. On the other hand leases are to some extent sui generis. Covenants for renewal contained in leases for over 2I years are sustained by authority. They may be supported on principle on the ground that they do not violate the policy of the rule even though they conflict with its letter. The question therefore is whether an option to purchase the fee, inserted in a lease for over 2I years, and exercisable at any time during the term, may be sustained as an exception to the rule, on the ground that it does not conflict with the policy on which the rule rests.

The policy behind the rule is undoubtedly to prevent one owner from unduly and unreasonably diminishing the value of ownership to his successors. The same policy also lies behind the companion rulethe rule against restraints on alienation-which prevents undue restriction of the right of alienation, which is one of the most valuable incidents of ownership. Property-especially real property-endures, while owners are ephemeral. Even an owner in fee is in a sense only a tenant for life with power of disposition. When in 1620 executory devises which would cut short vested interests were held to be

\footnotetext{
${ }^{28}$ London \& S. W. Ry. v. Gomm (I88I) 20 Ch. D. 562; Trevelyan v. Trevelyan (1885) 53 L. T. N. S. 853; Winsor v. Mills (1892) 157 Mass. 362 ; Barton v. Thaw (rgi4) 246 Pa. St. 348; Starcher v. Duty (I907) 6r W. Va. 373, 56 S. E. 527; Woodall v. Bruen (1915) 76 W. Va. 193, 85 S. E. 170; Gray, Perpetuities, s. 330 .
} 
indestructible, ${ }^{27}$ this power of disposition was enormously increased. Unless restrained by law, any given owner might, by the creation of these indestructible contingent interests, practically deprive his inevitable successors of all the benefits of ownership throughout an indefinite future. So long as the present estate may be cut short at any moment a large part of its value either for use or sale is gone. As a practical matter no one will either buy or efficiently improve a property which he may lose at any moment upon the happening of a contingency beyond his own control. Public policy clearly required an antidote for this situation. That antidote was the rule against perpetuities ${ }^{28}$ and its companion, the rule against restraints on alienation. ${ }^{29}$

Is there a real and practical distinction between an option in gross to purchase the fee, and an option to purchase the fee attached to a leasehold and exercisable only during the term? In the opinion of the writer there is. An option in gross exercisable at a remote period hangs over and threatens the present estate in possession. It operates as a practical clog on development and alienation alike, since present possessor and possible purchaser have a tenure dependent on the caprice of a third party. Neither objection applies to an option to purchase attached to and exercisable during a presently vested term for years. In the first place the option is in aid of the estate of the party in possession and therefore encourages him to develop that estate to its utmost capacity. In the second place it is not a serious detriment, if indeed any detriment at all to the reversion. The reversioner has in effect transformed his estate into a present right to receive rental from time to time and an ultimate right to receive the property back. Its value is measured to a considerable extent by that rental. It is but a short step to commute the recurring payments of rental into a single cash payment in full. In a word the business reasons which render a remote option in gross extremely injurious to an estate in fee do not apply if the option be attached to a presently vested term for years. Such an option neither retards development nor places the reversion extra commerciam.

There are strong business reasons why such an option should be permitted in leases for over 2 I years. In the first place such an option is frequently inserted in leases for less than that period-where no

${ }^{2}$ Pells v: Brown (1620) Cro. Jac. 590. See Gray, Perpetuities, ch. V for the origin and history of the rule.

${ }^{28}$ For the somewhat illogical and empiric manner in which the rule was developed, see Gray, Perpetuities, ch. V.

${ }_{2}$ The two rules are entirely distinct as Gray points out. Gray, Perpetuities, ch. VII. One prohibits the creation of remote future interests. The other forbids specific restraints on alienation beyond certain limits. See generally Gray, Restraints on Alienation. But both are the expression of public policy intended to protect each successive owner from unwarrantable clogs imposed by his predecessors. 
possible objection can be made under the rule. In the second place long leases are frequently made of unimproved property, the lessee to improve at his pleasure. It is extremely desirable that the parties to such leases should be able to fix in the lease their rights at the termination of the lease. Broadly speaking, there are only four possibilities: (I) to permit the lessee to buy out the lessor; (2) to permit the lessee to require the lessor to pay to him the then value of the improvements; (3) to vest the improvements in the lessor without payment, on the ground that they are incorporated in the real estate; (4) to permit the lessee to remove them so far as he can. The last two are for business reasons undesirable since they inevitably tend to the depreciation of the estate at the end of the term. The first two are equally open to objection, if specifically enforced, under the letter of the rule against perpetuities. So long as the law permits the creation of leases for a term which may exceed the period of the rule, it seems undesirable to invoke the rule in order to limit the parties in adjusting their rights at the termination of the lease in ways which are common and unobjectionable in shorter leases. In a word the rule was made for man, not man for the rule.

Indeed it may well be urged that public policy is remotely if at all concerned in such a case-once the right to make the long lease is admitted. The question involves the disposition of two estates, each equally vested. Both are ultimately to be gathered into one hand, either that of the lessor or that of the lessee. We have already seen that at any time during the term-whether it is over $2 \mathrm{r}$ years or notthe lessor may enter and terminate the lessee's estate for breach of condition. Wherein is it more undesirable that the lessee, by payment of a sum of money at any time during the term, should be able to unite both estates in himself? Indeed such a proceeding bears a strong analogy to the common-law right of the tenant in tail to bar alike the entail and reversion by leaving a fine or suffering a common recovery ${ }^{30}$ - a proceeding which has never been held to violate the rule. If there be any weight in this analogy it would seem that so far from frowning on the introduction of the option into long leases, public policy should favor it.

A further argument may be grounded on the fact that leases have been held to be in certain respects an exception to the rule against perpetuities and also to the rule against restraints on alienation. We have already seen that covenants for an indefinite series of optional renewals, or even for an optional renewal in perpetuity, are good. ${ }^{31}$ An optional covenant for a renewal in perpetuity is for practical pur-

\footnotetext{
${ }^{\infty}$ In most American states, estates tail are either abolished, or else may be barred by a conveyance in fee by the tenant in tail. And $c f$. also the rights of mortgagor and mortgagee: see Gray, Perpetuities, ch. XVI.

${ }^{81}$ See supra, sec. IV.
} 
poses substantially the equivalent of an optional covenant to convey the fee..32 So also covenants against assignment or underletting are universally sustained without question ${ }^{33}$ - a clear exception to the rule against restraints on alienation. If, as has been shown, options to purchase the fee inserted in long leases do not contravene the policy which underlies the rule, that exception to the letter of the rule may well be supported by the analogy of the two other exceptions just noted.

We turn to the authorities, which are few. In Woodall v. Clifton ${ }^{34}$ it was held that an option to purchase at any time during the term inserted in a lease for over 21 years will not be specifically enforced in equity. But the case was held to be governed by London \& $S . W . R y$. v. Gomm, ${ }^{36}$ which decided that an option in gross reserved in a conveyance in fee was invalid, and the court, without any extended argument, simply refused to follow the analogy of covenants for renewal in leases. Woodall v. Clifton has since been followed in Worthing Corp. v. Heather, ${ }^{36}$ in which, however, the covenant was held good at law and damages for its breach given against the estate of the covenantor. In Ireland a provision by which a perpetual rent charge might at any time be redeemed by payment of a fixed sum was sustained at first, but this decision was later overruled ${ }^{37}$ on the authority of the Gomm case and the other two English decisions just noted. In passing, it may be suggested that as a provision for relieving the estate from the encumbrance of a perpetual rent charge seems entirely in accord with the policy underlying the rule, this policy might well prevail over the letter. But it must be conceded that in England the letter of the rule has prevailed.

The writer has been able to discover only one American case which in express terms passes on and decides the question. Hollander $v$. Central Metal $\mathrm{Co}^{38}$ was a bill in equity to enforce specifically an option to purchase the fee contained in a lease for over $2 \mathrm{I}$ years, to which there was a demurrer on the ground that the option was bad under the rule. The case was fully argued and the English cases ${ }^{39}$ as well as the authority of Mr. Gray ${ }^{40}$ were all cited in support of this latter view. After full consideration the court held the option good, principally upon the ground that even if it conflicted with the letter of the

sx Gray, Perpetuities, s. 230.

"Gray, Restraints on Alienation, ss. IOI-I03.

${ }^{34}$ [1905] 2 Ch. 257.

${ }^{20} 20 \mathrm{Ch}$. D. 562.

"Switzer" v. Rochford [1906] I Ir. 399.

${ }^{3}$ In re Tyrrell's Estate [1907] I Ir. 292; In re Earl of Donoughmore's Estate

[IgII] I Ir. 2II.

${ }^{29}$ (I908) $109 \mathrm{Md}$. I3I.

* See supra, notes 34-37.

${ }^{*}$ Perpetuities ( $2 \mathrm{~d}$ ed.) s. 230. 
rule it was not in conflict with its underlying policy. ${ }^{41}$ This case is of unusual interest and authority because it was decided after full consideration of the cases which upheld and followed the letter of the rule.

In addition there is some American authority which has upheld such options inserted in long leases, but without consideration of the rule. Thus in Prout $v$. Roby, ${ }^{42}$ specific performance was given of an option to purchase the fee inserted in a lease in perpetuity. ${ }^{43}$ And a similar decision was rendered in Hagar v. Buck $k^{44}$ as to a similar option inserted in a lease for 99 years. It is true that in neither of these cases was the validity of the option under the rule specifically considered. Yet since specific performance was granted, the point was of necessity involved in the decision. Moreover the fact that the point was not specifically considered may perhaps be some indication that the result does not conflict with the policy of the rule even if it be con-. trary to the letter.

Finally if the letter of the rule be still considered a stumbling-block, the results may conceivably be attained by care in drawing the lease. The term of the lease may be made 20 years, with an option to purchase during the term, and a covenant be inserted for an indefinite series of renewal leases, each containing a similar option. We have already seen that covenants for renewal are good. ${ }^{45}$ And each renewal automatically creates a new option which is good for the renewal term. ${ }^{40}$ Indeed a similar result might possibly be reached by a covenant for renewal in perpetuity upon payment of a specified amount in lieu of all rental. If by either of these methods the result may be reached without violating even the letter of the rule, an exception to its letter may well be made in the case where the option to purchase it attached to a term of over 2I years. Again the question becomes one of form rather than one of substance.

VALIDITY AT LAW OF CONTINGENT COVENANTS WHICH MAY NOT BE PERFORMED WITHIN THE PERIOD OF THE RULE

The rule is a rule of property, not a rule of contract. It does not affect the validity at law of contingent covenants or contracts which

"1. The local custom of making leases containing such options was undoubtedly a factor in the result.

(I872) 15 Wall. $47 \mathrm{I}$.

For dicta to the same effect see Wells v. Savannah (Igor) I8I U. S. 53I, 544; York County Sav. Bank v. Abbot (1905, C. C. D. Me.) Fed. 988.

" (1872) 44 Vt. 285.

"Supra, sec. IV.

"s And as we shall see, post, sec. VI, the convenant is good at law. But cf. Starcher v. Duty (1907) 6I W. Va. 373, 56 S. E. 527. On this point this case is not to be supported, as the successive options are plainly separable. Cf. Gray, Perpetuities, ch. IX. 
may not be performed within the period of the rule. ${ }^{47}$ It is true that specific performance in equity may be denied, on the ground that the effect of such performance if granted would be to create remote contingent estates. ${ }^{48}$ Yet the covenant or contract is still valid at law, and the covenantor must respond in damages for a breach of it."

The leading case is Walsh $v$. Secretary of State for India.9 In I770, Lord Clive transferred $£ 62 ; 000$ to the East India Co. under a sealed agreement by the company to pay the interest upon an equal sum in pensions to European officers disabled in its service, and in the event that the company should ever cease to employ military officers in its service, to repay an equal sum to Clive or his representatives. In 1858, after the Sepoy Mutiny, Parliament transferred the forces and property of the company to the crown, but subject to the obligations of the company. This was a bill in equity by the then representatives of Clive to compel repayment of the $t 62,000$. It was held that the covenant was valid and enforceable as a covenant, though the condition might not happen within the period of the rule.

A very neat illustration of the distinction between the equitable and legal enforcement is furnished by Worthing Corp. v. Heather, ${ }^{50}$ which was a bill in equity to compel specific performance of an option to purchase the fee inserted in a lease for 30 years, and in the alternative to recover damages against the covenantor for breach of it. The court denied specific performance on the ground that such relief would in effect create a contingent equitable estate which would be too remote, but held the covenant valid at law and entered a decree for damages. ${ }^{51}$ There could be no clearer illustration of the distinction between the contract and the property aspects of the same covenant.

VII

\section{CONCLUSIONS}

It seems that to some extent leases are subject to the rule and to some extent are an exception to it. The authorities seem to support the following conclusions:

\footnotetext{
"Gray, Perpetuities, s. 329; Walsh v. Secretary of State (1863) 10 H. L. 367; Witham v. Vane (1883, H. L.) reported in Challis, Real Prop. (3d ed.) 440; Borland's Trustee v. Steel Bros. [I90I] I Ch. 279; Worthing Corp. v. Heather [1906] 2 Ch. 532.

${ }^{4}$ See supra, note 26.

( $(1863$ ) Io H. I. 367 . It may be noted that the covenant did not require reconveyance of a specific trust estate, but merely payment of a sum equal to the original gift.

${ }^{50}[\mathrm{Ig06}] 2 \mathrm{Ch} .532$.

${ }^{81}$ Cf. Winsor $v$. Mills (1892) I57 Mass. 362 , where specific performance was - denied, but performance of the covenant enforced as the condition of equitable relief to the convenantor.
} 
I. The rule prohibits the creation of contingent terms for years which may not vest or fail within the period of the rule. On the other hand, a presently vested term limited to take effect absolutely at a time which under the letter of the rule would be remote appears to be good.

2. Since the reversion after a term of years, no matter how long, is a vested estate, conditions are valid which accelerate that vested estate, even though they are contingent and not certain to take effect or fail within the period of the rule.

3. Covenants for renewal at the option of the lessee, exercisable at any time during the term, are an exception to the letter of the rule, and are sustained by the great weight of authority, even though the term be so long that the option may be exercised at a time beyond the period of the rule.

4. There is conflict as to the validity of options to purchase the fee at any time during the term, inserted in leases for terms of over 2I years. They certainly conflict with the letter of the rule. In England the letter of the rule prevails and specific enforcement of such options is denied. In this country such authority as there is seems to sustain them. In Maryland specific enforcement has beęn granted after mature consideration, on the ground that they do not conflict with the policy of the rule. In the Supreme Court of the United States and in Vermont they have been specifically enforced without consideration of the rule. In the opinion of the writer the broader American view should prevail over the letter of the rule, since such options in leases do not conflict with the policy of the rule and the result may be attained without conflict with even the letter of the rule by a mere change in form. Similar considerations do not, however, apply to remote options in gross attached to a conveyance in fee, which seem to be universally condemned.

5. Since the rule is a rule of property and not a rule of contract, contingent contracts or covenants are good at law even though the condition will not happen or fail within the period of the rule. If, therefore, such a covenant be broken, damages at law may be recovered from the covenantor. 